\title{
The Role of Authentic Green Bureaucracy in Green Village Innovation Plan in Yogyakarta Special Region (Daerah Istimewa Yogyakarta)
}

\author{
A. T. Sulistiyani ${ }^{1}$, Sutarno $^{2}$, Prabang Setyono ${ }^{3}$, R. D. Wahyuningsih ${ }^{4}$ \\ \{atsulis@yahoo.co.id ${ }^{1}$, nnsutarno@mipa.uns.ac.id ${ }^{2}$, prabangsetyono@gmail.com ${ }^{3}$, \\ rutiana.uns@gmail.com ${ }^{4}$ \}
}

Doctoral Program of Environmental Science, Postgraduate School, Sebelas Maret University, Jl. Ir. Sutami No. 36A, Surakarta, 57126, Indonesia ${ }^{1}$, Dept. of Biology, Faculty of Mathematics and Natural Sciences, Sebelas Maret University, Jl. Ir. Sutami No. 36A, Surakarta, 57126, Indonesia ${ }^{2,3}$, Faculty of Social and Political Sciences, Sebelas Maret University, Jl. Ir. Sutami No. 36A, Surakarta, 57126, Indonesia ${ }^{4}$, Dept. of Public Policy and Management, Faculty of Social and Political Sciences, Gadjah Mada University, Jl. Sosio Yustisia No.1, Sleman, 55281, Indonesia ${ }^{1}$

\begin{abstract}
Green village is one residential innovation form that should be supported by bureaucratic role, particularly The Department of Environment (Dinas Lingkungan Hidup) of Yogyakarta Special Region. Government spirit is increased to develop green village as the ideal settlement. Pattern relationship between bureaucracies will encourage the formation of bureaucratic atmosphere in developing green village. Government should facilitate the green village development and support the local environmental cadres as motivator. This paper discusses the roles of authentic green bureaucracy in facilitating green village innovation program in Yogyakarta Special Region. This research was performed with qualitative approach and document analysis. This document aims to find out the roles of authentic green bureaucracies to develop green village innovations in Yogyakarta Special Region. The authentic role of green bureaucracy done by The Department of Environment covers planning but in limited ways. The green village planning role is too macro. The authentic role of The Department of Environment of Yogyakarta Special Region should be developed to become bureaucracy which is environmentally friendly in a whole and continuously. That ability can be achieved by improving the conceptual capability versus operational technique, coordination and supervision ability as well as discretion ability..
\end{abstract}

Keywords: Green Village Innovation, Authentic Green Bureaucracy, Bureaucracy Roles, Innovation Plan.

\section{Introduction}

In general, development always takes resources. Each development is followed by a great deal of resources to fulfill the requirement of construction and production process which are started from consumption need. Thus, development is often stumbled by a contradiction fact where in one side it leads to a better condition but it also causes environmental degradation in the other side. Regardless, development always puts economy as the commander that economic growth comes first than environmental conservation. The important fact of sustainable development which puts forward nature conservation should be popularized. In 
fact, environmental development paradigm which has been understood has not been realized in general yet.

Although conceptual and science awareness has developed really fast yet the implementation effort for environmentally-friendly-development goes really slow. Political environment in government bureaucracy is still on theory perspective in considering environmental problems. Leonard (2018) ever said that political ecology has focused on theoretical perspectives. In Indonesia, on the level of bureaucracy politic, environmental perspective has been expressed through campaigns of legislative candidates and region head prospects, as well as in speech material of bureaucrats. The realization effort of environmental development in urban and rural areas are still really limited. Environmental quality can be improved if government bureaucracy is able to perform distribution and management for urban green space. Danjajiet all (2018) explained that systematic distribution and management strategy of urban green spaces has proved to have positive impact (positively influenced) on aesthetic features of urban environment. However, indeed, there are a lot of factors which are hampering to reach urban green space. In order to cope with this problem, according to Poor and Thrope (2017), pro-environmental behaviour is capable of moderating the barriers.

In policy level, regulations have had partiality to the importance of environmentallyfriendly-development. Meanwhile, on the implementation, they have not been able to execute the spirit of environmental conservation with real movements. The formalization of programs and activities has been able to be formulated in every regions yet has not gained the action awareness from the bureaucrats. Program formulation which expresses the spirit of environmental conservation is green village. Government bureaucracy should develop the spirit of green bureaucracy in a long term. Thus, sustainable development can be realized in a long term. Balasubramanian (2018) conveyed that long-term development is a process of accumulation and sound management of a portfolio of assets-manufactured capital, natural capital, human and social capital.

Green perspective bureaucracy concerns on the innovation such as green villages. This innovation is basically complex (Kristina, 2010). According to Fredayani (2018), one type of village innovation is $3 \mathrm{G}$ Village (Glintung Go Green) which is a solution in achieving the goals containing in SDG's program. Another village innovation, stated by Puspitasari (2014), is a Gayamsari Green Village Program that prioritizes friendly environmental development. All provinces conduct village development program including Special Region of Yogyakarta (DIY). It has 45 green villages in all over DIY.

Local government which has multisectoral bureaucracy structure requires clear roles of the bureaucracy in developing green village. Roles between actors in public bureaucracy are really important, as has been conveyed by Johnstone at al. (2017) that multilateral actor-toactor (A2A) networks are substantial. However, the problem on green village does not only need supports from the bureaucracy role but also from society participation. Negative impacts emerge from settlements. Green village program aims to maintain settlement environment in clean, healthy, manage and green condition. Society has to contribute through their care for public space, open green space, and settlement facilities as public goods. Related to society awareness, Halimatussadiah, et.all. (2017) said that people have willingness to pay for a public good. Problems which are encountered by bureaucracy related to the context of green village is that they have not been able to determine the active roles. This article discusses the authenticity of bureaucracy roles in green village program in DIY. 


\section{Research Method}

This study used qualitative and quantitative descriptive approach by prioritizing data of information, words and explanations obtained from primary and secondary resources. Analysis unit of this research were government institutions. Local government institutions being analyzed were Yogyakarta Special Region Government related to the development substance of green village innovation. The institution which became the focus of analysis was The Department of Environment, which had the authority to develop green villages. The data collection technique was done by interviewing 10 staffs as key informants of bureaucrats in the Department of Environment, as well as documentation, by observing scripts, strategic plan and green village review. They key informants consisted of 6 males and 4 females. The perceptions about the authentic role of green bureaucracy was obtained from 30 respondents. Their perceptions were calculated using percentage. The analysis used in this research were descriptive qualitative and quantitative by establishing the illustration of authentic roles of green bureaucracy.

\subsection{General Bureaucratic Role}

Bureaucracy is a place to cover government activities, development and public services. Bureaucracy is also a tool or medium used by government to execute visions, missions and goals of a country. Therefore, bureaucracy in visual is performed in the form of government institutions. The static form of bureaucracy is shown through organizational structure. The dynamic form of bureaucracy is expressed through visions, missions, goals, policies, work plans and programs, descriptions of job desk and function as well as apparatus. Meanwhile, the technical form of the operational can be seen from the activities of the apparatus in performing the job desks and functions. Eme and Emeh (2012) said that bureaucracy is that apparatus of government designed to implement the decisions of political leaders. Gonçalves (2013.p.606) stated that bureaucracy have highlighted the ways in which the production, circulation, interpretation, and archiving of written documents contributes to the production of state power, control, and authority. In brief, bureaucracy is apparatus composition which gets the mandate to support the operations of all political policies. It is true if bureaucracy is to be said as a tool to reach political goal. Thus, bureaucracy is located on the second layer after political leader.

Bureaucracy has strategic plan in government, development, and public service. The role carried out by bureaucracy in general covers administrative and substantive roles. Substantive role, according to Eme and Emeh (2012.p.34) is policy formulation and implementation responsibilities. In the context of bureaucracy according Vanhoonacker, Dijkstra and Maurer (2010.p.21), substantive role also hasan important role in formulating the questions and sharpening the arguments. Policies formulation is the follow-up action in delivering political mandate received from legislative. Government regulation documents, development plans, public service system and procedure are the real form of administrative roles. Administrative roles are presented as the role of administrative actors (Vanhoonacker. Dijkstra.And Maurer.2010.p.4). In order for the program run effectively, according to Gonçalves (2013.p614-615) District Councils were expected to play a key role in monitoring financed projects, role in providing information, and local commission for the evaluation of projects. Harvey in Schiller and Maria. (2017.p.1665) explained that the role of the state in such a neoliberal framework is to preserve an institutional framework appropriate to such practices. 
According to Budisetianto and Andreas (2015. P.1), the administrative role of bureaucracy is the role of communication and the ability to present.

Most often, role is determined by position and status, the role of central bureaucracy is certainly bigger but macro compared to province and regency/city. Bureaucracy has position which is determined formally and regulated by regulations. Moreover, the nomenclature of an institution has illustrate the formal status and position in its relationship with government system. Bureaucracy status or position is an important variable in considering the role. David (2016.p.15) conveyed that the role this variable plays in other venues. As has been stated, the primordial role played by institutional aspects, reflected in the proposition ,where you stand depends on where you site (Cézar. 2017. 205). Bureaucracy on the low level encounters problems in public direct service. Meanwhile, bureaucracy on the high level has more jobs on arranging policies. David (2016.p.4) stated that the role of street-level bureaucrats has shown influence to the provision of public service programs. The amount of street-level bureaucracy really depends on the extent of the leader"s discretion. Although government bureaucracy has been entering modern management era where everything is advanced, yet the primordial role cannot be removed. Bureaucracy position and status really determines role. The roles of the low line bureaucracy position are determined by the level of the discretion by leaders. The extent of the discretion determines the coverage of the role played. Meanwhile, the roles of the low line bureaucracy have influence on the continuity of service operations and the execution of programs. The continuity of the low line bureaucracy will be determined by the result of the performance evaluation. According to Bowornwathana and Poocharoen "s opinion, their performance evaluation is seen from their goal achievement(2010.p.314). It means that through observation on the roles done by bureaucracy, the work can be evaluated.

\subsection{The Authenticity of Green Bureaucracy Roles}

Authenticity can be seen from two aspects, which are the purity of human resources spirit in one side, and administrative originality aspect. The purity in performing bureaucracy role shapes the characters in taking decisions, implementing policies, establishing networks, management and evaluations. Developing straightness in individual to behave and act with sincerity is the practice of authenticity. Good intention to finish every responsibilities, functions and jobs dynamically is really important. Authenticity in relation to leadership appears as the premise of being true of one's self as sincere, honest, and integrated person (Ford and Harding, 2011). Authentic leardership has been admitted as a psychological influence on giving positive impact towards working performance (Nelson, et. al., 2014).

Although the authentic role of green bureaucracy has been admitted to be important, yet it is still not easy to be implemented. Leader"s policies and behaviors really determine the success of bureaucracy authentic role. Avolio\& Gardner (2005) said that in general, all suggest that authenticity has its starting point with the leaders themselves, through their selfawareness, self-acceptance, self-knowledge, faith, actions and relationships, promotion of authentic relationships with their followers and associates, supported by transparency, trust, integrity and highmoral standards. Other opinion has been delivered that being authentic means "be true to yourself" (Wong\& Cummings, 2009; Walumbwa et al., 2008; Avolio\& Gardner, 2005).

Dickinso, (2011.p.9) put a definition of authenticity, as a means of encapsulating all of these individual constructs and discussing the dynamic way in which they intertwine to become the relationship. The definition delivered by Dickinso is authenticity in context of developing network role. Authenticity is not easy to be shaped, except through a long and 
gradual process with good comprehension for many aspects. Smith (1991);Dickinso, (2011.p.9) also mentioned that authenticity as a reflexive process, whereby, the concepts of trust, longevity and knowing are incrementally built up through multiple iterations over time. Based on this opinion, the purity of human resources spirit in implementing bureaucracy roles are determined also by the process in organization. In the other side, bureaucracy is also related to document authenticity. Gonçalves. (2013. p.620) proposed that authenticity is obtained by special treatment of the written document. According to Budisetianto and Andreas (2015. P.3), authenticity principle in Public Administration in national and even international context needs to be more improved. The focus of this research is to analyze the authenticity of bureaucracy roles, not document authenticity.

The concept of authenticity comes to be operational when it is linked to the role carried by bureaucracy. Brumbaugh (1968.p.2) stated that authenticity concept to make it empirically operational is to link it to role theory. A bureaucracy ought to be able to ensure the amount of role authenticity which can be done that it leads to the achievement of the goal. In the other side, bureaucracy should ensure whether there is role deviation which does not fit the goal or not. The authenticity of bureaucracy role is a continuum line which can be measured start from the extreme pole of the most deviant behavior until the extreme pole of the most authentic behavior. Conveyed by Brumbaugh (1968.p.2), authenticity may be conceptualized as some points on the role distance continuum ranging from behavior perceived as expressing complete embracement of a particular role through behavior perceived as expressing complete alienation from a particular role. This authenticity coverage is related to human inherence, morality, mentality, values and behaviors.Besen.et.al. (2017.p.2) conveyed that it is based on the assumptions of authenticity and strong ethical/moral values. Identification of the main task and function of bureaucracy should be undertaken in order to find out the bureaucracy roles. The types of program and activity, budget support, as well as the frequency of activity and program are able to express the authentic role of bureaucracy.

The types of the main role of bureaucracy are conceptual, implementation management, operational and evaluation. In order to gain the authenticity of bureaucracy roles, tracking inside the form of operational activities is required. Visually, the authentic role of bureaucracy should be able to be tracked in the most technical, operation and real form. The authenticity concept is an effort to provide more clearly to the latter and the end to facilitate its empirical operationalization. Meanwhile, research which is done related to the authenticity of bureaucracy role requires verification towards the object. In order to obtain valid data, it is important to observe the effects caused. According to (Lynch. 2000.p.40) validating authenticity entails verifying claims that are associated with an object-in effect. Identity expression in form of self-image will determine public image. Meanwhile, yision, personality, values, competency, performance, and origin determine authenticity. Likewise, public image is shaped from external behavior, as the following Hitzler model: Pubtio imago

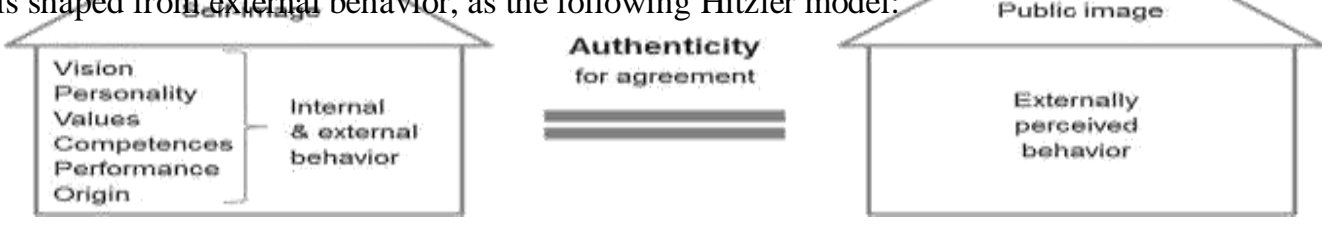

Picture 1. Image and Authenticity

Source: Hitzler (2017.p.35) 
The authenticity of bureaucracy role cannot be separated from the bureaucracy's internal and external behavior in performing management roles of the organization. The authenticity of conceptual roles cover planning and formulation of public policies, implementation roles cover process management, operational roles cover technical follow-up, while monitoring and evaluation roles cover supervision, validation and assessment, which are done proportionally according to bureaucracy function allocation.

Green bureaucracy has role sensitivity which prioritizes the presence of green, balanced and sustainable internal and external environment. The purity of green bureaucracy role is inspirited in daily activities. In formal and informal, bureaucracy shows commitment toward the importance of preserving environmental conservation. Spirit of programs is not always only for the sake of formal goal, but to control the effects toward environment. Authentic roles of green bureaucracy cover the ability in planning, the spirit to implement environmental conservation through the execution of bureaucracy task and function proportionally, realizing bureaucracy program and activities synergized with environmental safety, preventing the occurrence of negative impact from program and project as well as recovering from damage. Green, healthy and organized environment is public good which has to be established, preserved, and conserved. Bureaucracy ought to has authentic role along with the vision, mission, and goal. A green bureaucracy is able to actualize authentic role toward internal and external environment. The authentic role of green bureaucracy can give exemplary to society. Therefore, society has the awareness of the importance of green, clean, healthy, and organized environment. According to Yao (2015.p15.) explained that one of the goal is coordinated exploration of past policy actions and possible future trajectories.

\subsection{The Green Village Innovation Plan in Yogyakarta Special Region}

Autentic role of bureaucracy is required in green village program. Honesty, sincerity, and integrity should be the main principles of government bureaucracy in order to develop bureaucratic climate. Green bureaucracy can build green villages. Green bureaucracy has environmental perspective. Environmental bureaucray can comprehensively carry out green village plan innovation. Innovation is very important as the learning process (Van Auken, 2008). Regional innovation system relates to creating framework which aims on systematic promotion of learning process (Barasa, et. al., 2017). Innovative villages are those that can use their own resources in different or new ways with technology and local wisdom for the society prosperity. Green village innovation can improve the quality of environment. According to Sutiyo and Nurdin (2015), innovative village can assist villagers solve their livelihood problem.

\section{Finding And Discussion}

The DIY government has laid a strong foundation in planning innovation. DIY Government Policy in planning emphasizes synergic processes between parties, so that there is effective participation. The development planning process also applies a measurement system so that policy consistency occurs. In addition, planning also considers the completeness of the elements of planning and innovation. 

Table 1 Development Planning Indicators

\begin{tabular}{|l|l|c|c|}
\hline \multicolumn{1}{|c|}{ Strategic target } & \multicolumn{1}{|c|}{ Performance indicators } & $\begin{array}{c}\text { Target for } \\
2017(\%)\end{array}$ & $\begin{array}{c}\text { Program } \\
\text { realization }\end{array}$ \\
\hline \multirow{3}{*}{ The realization of synergic, } & Percentage of planning synergy & 95 & 105,26 \\
\cline { 2 - 5 } measurable, consistent, & Percentage of planning measurement & 90 & 111,11 \\
\cline { 2 - 5 } innovative regional & Percentage of planning consistency & 90 & 111.11 \\
\cline { 2 - 5 } development planning. & Percentage of complements of planning & 92 & 108.70 \\
\cline { 2 - 5 } & Percentage of participation in planning & 90 & 111,11 \\
\cline { 2 - 5 } & Percentage of innovation planning & 95 & 105,26 \\
\hline
\end{tabular}

Source: Lakjip DIY (2017:26)

Based on the data above, the plan performance of Special Region of Yogyakarta achieves excellent rank. The $95 \%$ of plan performance target was already very high, even the performance achievement is much better in the amount of $105.26 \%$. This research explored the role of green bureaucracy in green village innovation plan.

The authentic roles of green bureaucracy cover planning of programs which are environmentally-friendly. The Department of Environment has performed green village innovation activity facilitated by Regional Development Expenditure Budget. Budget allocation shows that dominantly, green village plot demonstration activities worked continuously in two years, however it did not receive allocation anymore in 2015-2016. The continuous vision of green village program was disconnected. In order to keep the continuity of green village program, environmental cadres were formed. However, explicitly, the existence of environmental cadres could not be seen. The formation of environmental cadres only worked for a year and there was no continuity. Meanwhile, green village empowerment was initiated in 2016 with a very limited proportion. The authentic role of The Department of Environment of Yogyakarta Special Region to support green village innovation.

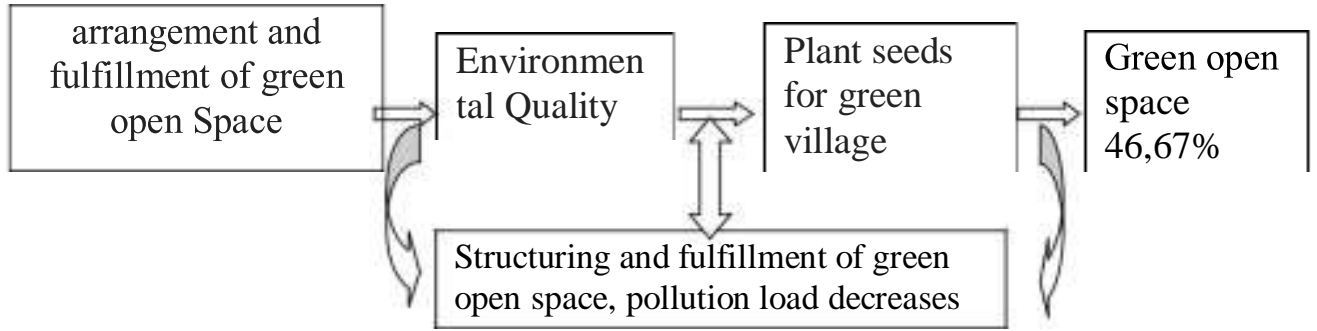

Picture 2.Bureaucratic role in green village innovation 
The role of The Department of Environment in planning is presented on the availability of strategic plan document, vision, mission and goal. Formally, planning role is fulfilled. Substantially, planning role which is composed in village innovation, particularly green village is still partial. Green village program is still very minimal. Based on in-depthinterview, the bureaucracy does not understand well the values of itself. Misunderstanding of green bureaucracy concept can be seen from the activity of each division which does not have direct relationship with green innovation. The data of each division can be seen in the following table:

Table 2 The Department Environment Activities of 2017

\begin{tabular}{|l|r|r|c|}
\hline \multicolumn{1}{|c|}{ Division } & Activity & $\%$ & $\begin{array}{c}\text { Relationship With The Green } \\
\text { Village Innovation } \\
\text { (Direct/Semi/Indirect) }\end{array}$ \\
\hline Sub division of Conservation & 35 & 43.20 & semi direct \\
\hline $\begin{array}{l}\text { Sub division of Environmental Damage } \\
\text { Control }\end{array}$ & 18 & 22.22 & indirect \\
\hline $\begin{array}{l}\text { Sub division of Development of Human } \\
\text { Resources and Environmental Institutions }\end{array}$ & 8 & 9.88 & Direct \\
\hline $\begin{array}{l}\text { Sub division of Environmental } \\
\text { Arrangement }\end{array}$ & 5 & 6.18 & Indirect \\
\hline Sub division of Environmental Studies & 3 & 3.71 & Indirect \\
\hline Sub division of Air Pollution Control & 7 & 8.64 & Indirect \\
\hline $\begin{array}{l}\text { Sub division of Water Pollution, Soil and } \\
\text { Hazardous and Toxic Control Materials }\end{array}$ & 5 & 6.17 & \multicolumn{1}{|c|}{. } \\
\hline Number of activities & 81 & 100 & $9.88 \%$ direct, 43.20 semi direct \\
\hline
\end{tabular}

Source : Dokumen Kinerja Pengelolaan Lingkungan Hidup Daerah, DIY, 2017

Based on the data, there were only $9.88 \%$ activities which had direct relationship to green village innovation program. Furthermore, there were $43 \%$ of semi direct activities related to green village innovation. Meanwhile the indirect activities related to green village innovation were $46.92 \%$. The program portion was very small compared to other activities. Based on indepth-interview, the activities were not speficit for green village innovation program. For instance, Water Pollution, Soil, and Hazardous and Toxic Control Materials were only for specific area and not for the village. Conservation was implemented for critical area but not for the village and so on.

The Department of Environment are facilitating the formation of autonomous waste management community and improving waste management with 3R concept (Reduce, Reuse, Recycle) in society base. Autonomous waste management community and $3 \mathrm{R}$ concept implementation only become the small part of green village curriculum. These two strategies are not enough to support and facilitate the development of green village optimally.

Facilitating the development of green village should had been put in the strategy in order to create coherency between strategy formulation with program formulation by identifying authentic green bureacracy innovation. 
Table 3 Respondent's perception about the role of authentic green bureaucracy

\begin{tabular}{|l|c|c|c|c|c|c|c|c|c|}
\hline \multirow{2}{*}{ Activities } & \multicolumn{9}{|c|}{ Percentage } \\
\cline { 2 - 10 } & \multicolumn{2}{|c|}{$\begin{array}{c}\text { Sincerity to create green } \\
\text { villages }\end{array}$} & \multicolumn{2}{|c|}{$\begin{array}{c}\text { Honesty to create green } \\
\text { villages }\end{array}$} & \multicolumn{3}{|c|}{$\begin{array}{c}\text { Integrity to create green } \\
\text { villages }\end{array}$} \\
\cline { 2 - 10 } & $\begin{array}{c}\text { Commi } \\
\text { t-men }\end{array}$ & $\begin{array}{c}\text { Contribu } \\
\text {-tion }\end{array}$ & $\begin{array}{c}\text { Consi } \\
\text { s-tent }\end{array}$ & $\begin{array}{c}\text { Propo } \\
\text {-sal }\end{array}$ & $\begin{array}{c}\text { Actio } \\
\mathrm{n}\end{array}$ & $\begin{array}{c}\text { Realiz } \\
\text { a-tion }\end{array}$ & $\begin{array}{c}\text { Princi } \\
\text {-ple }\end{array}$ & $\begin{array}{c}\text { Faith } \\
\text {-full }\end{array}$ & $\begin{array}{c}\text { Respo } \\
\text { n- } \\
\text { sibilit } \\
\mathrm{y}\end{array}$ \\
\hline $\begin{array}{l}\text { Programmin } \\
\text { g }\end{array}$ & 83,47 & 78,79 & 80,73 & 85,81 & 83,48 & 79,93 & 89,33 & $\begin{array}{c}81,8 \\
8\end{array}$ & 86,18 \\
\hline $\begin{array}{l}\text { Planning of } \\
\text { activities }\end{array}$ & 79,86 & 75,68 & 77,61 & 83,93 & 80,96 & 80,59 & 84,91 & $\begin{array}{c}85,6 \\
8\end{array}$ & 84,63 \\
\hline Budgeting & 90,05 & 82,57 & 88,43 & 92,28 & 90,77 & 89,53 & 87,89 & 90,1 & 89,59 \\
\hline
\end{tabular}

Source: primary data, 2018

It shows that the authentic role of The Department of Environment of Yogyakarta Special Region as bureaucracy which is environmentally-friendly is still limited. The barriers are difficulty in coordination among bureaucracy, limited budget allocation, lack of integration for green village program, ego in each division, and the absence of advocates for green village innovation.

Thus, in order to undertake the authentic role of green bureaucracy, there should be improvement in planning role. In planning role, improvement should be done in the ability of macro conceptual approach and micro technical operational. The Department of Environment needs to improve the quality of the village green innovation plan comprehensively. The data show that bureaucratic needs to understand green village innovation comprehensively. Thus the ability to make the proper plan can be achieved, interaction among stakeholders and the technical approach can be improved.

\section{Conclusions And Recommendations}

The authentic role of green bureaucracy in green village innovation carried by The Department of Environment of Yogyakarta Special Region has not been fully executed. Limitation in planning, designing, information and technical formation of the implementation of green village innovation indicates the limitation in concept comprehension of green village. Therefore, the authenticity of green bureaucracy of The Department of Environment of Yogyakarta Special Region has only been performed in only small part.

In order to perform improvement for the authentic role of green bureaucracy, these following efforts are required.

a. Strengthening the concept comprehension of green village innovation.

b. Strengthening the planning ability of green village innovation until the formation of guidance/technical direction can be documented well.

c. Repositioning the authentic role of The Department of Environment to the conceptual level and doing coordination with the related parties.

d. Improving the authentic role of green bureaucracy requires improvement in conceptual versus operational technique ability, coordination and supervision ability as well as discretion ability. 


\section{Reference:}

[1]. Badan Lingkungan Hidup Daerah Istimewa Yogyakarta. 2015. Laporan Tahunan: Pelaksanaan Program/Kegiatan Tahun 2014. Blh Diy. Yogyakarta.

[2]. Badan Lingkungan Hidup Daerah Istimewa Yogyakarta. 2016. Laporan Tahunan: Pelaksanaan Program/Kegiatan Tahun 2015. Blh Diy. Yogyakarta.

[3]. Badan Lingkungan Hidup Daerah Istimewa Yogyakarta. 2017. Dokumen Informasi Pengelolaan Lingkungan Hidup Daerahdaerah Istimewa Yogyakarta Tahun 2017. (Buku 1). Blh Diy. Yogyakarta.

[4]. Badan Lingkungan Hidup Daerah Istimewa Yogyakarta. 2017. Laporan Tahunan: Pelaksanaan Program/Kegiatan Tahun 2016. Blh Diy. Yogyakarta.

[5]. Balasubramanian, M. (2018).Inclucive Wealth Accounting For South Asia : Measuring Towards Sustainability. International Journal Of Environment And Sustainable Development.17(1). Pp. 3655 .

[6]. Barasa, Laura. Joris Knoben. Patrick Vermeulen. Peter Kimuyu And Bethuel Kinyanjui. 2017. Institutions, Resources And Innovation In East Africa: A Firm Level Approach. Journal Of Home Age: Www.Elsevier.Com/Locate/Respol. Research Policy 46 (2017). Pp: 280-291.

[7]. Besen, Fabiana. Edivandrotecchio.Francisco Antônio Pereira Fialho.(2017). Authentic Leadership And Knowledge Management .Gest. Prod. São Carlos. 24 (1). Pp. 2-14.

[8]. Bowornwathana, Bidhya And Ora-Ornpoocharoen. (2010). Bureaucratic Politics And Administrative Reform: Why Politics Matters.Journal Public Organization Review.10(4.December 2010).Springer.Pp.303-321.

[9]. Brumbaugh, Robert B. (1968). Authenticity, Role Distance, And Organizational Climate: Toward A Conceptual Clarification. Paper Presented At The Annual Meeting Of The American Educational Research Association (Chicago. Illinois, February 9, 1968).Pp.2-10.

[10]. Budisetianto And Jeffrey Andreas. (2015). The Role Of Record Managementin Revitalizing Government Bureaucracy. Development Agenda. Call For Inputs Unpan. Pp.1-3.

[11]. Cézar, Rodrigo Fagundes. (2017). When And How Do Bureaucratic Conflicts Matter In Trade Policy? Evidence From The Us Trade Policymaking Process During The Clinton Administration (1993-2001).Contextointernacional. 39(1. Jan/Apr 2017). Pp.201-222.

[12]. Danjaji, Abdulrahman Sa'adu. Mariani Ariffin. Amir Hamzah Sharaai And Yazid Mohammad Yunos. (2018). Impact Of Urban Green Space Attribute On Visitors Satisfaction In Putrajaya: Malaysia. International.Journal Of Environment And Sustainable Developmen.17(1). Pp. 19-35.

[13]. David, Jason. (2016). Representative Bureaucracy, Street-Level Bureaucrats And Bureaucratic Discretion In Federal Disaster Assistance.Journal Of Public Management And Social Policy.23(2).Pp.1-19. Development.16(4). Pp. 315-335.

[14]. Dickinson, J. Barry. (2011)The Role Of Authenticity In Relationship Marketing.Journal Of Management And Marketing Research.Pp.1-12. Diversity Officersasmodern Public Officials." Journal Of Ethnic And Migration

[15]. Eme, Okechukwu Innocent And Emeh, Ikechukwu Eke Jeffry. (2012). "Bureaucracy And Rural Development; The Role Of Public Administration In National Development: The Nigerianperspective."Global Journal Of Management And Business Research.12 (4.Version 1.0 March 2012). Pp. 18-40.

[16]. Ford, Jackie And Nancy Harding, 2011. "The Impossibility Of 'True Self' Of Authentic Leadership,” Leadership Journal. 7(4). Lea.Sagepub.Com. Pp: 463-479.

[17]. Fredayani, Ervina. 2018. Kampung 3g (Glintung Go Green): Local Idea As Global Solution? Journal Of Social Politics. 4 (2. July - December 2018). Pp: 152-168 .

[18]. Gonçalves, Euclides . (2013). Orientaçõessuperiores: Time And Bureaucratic Authority In Mozambique Published By Oxford University Press On Behalf Of Royal African Society. All Rights Reserved. Pp. 602-622.

[19]. Government And Bureaucracy.Policy Brief.24 (Januari 1999) Equity And Growth Through Economic Researchan Activity Of Usald, Bureau For Africa, Office Of Sustainable Development, Strategic Analysis Division. 
[20]. Hitzler, Patricia Anna And Günter Müller-Stewens. (2017). "The Strategic Role Of Authenticityin The Luxury Business.” Dalam M.A. Gardetti (Ed.). Sustainable Management Of Luxury.Environmental Footprints And Eco-Design Of Products And Processes.Springer Nature Singapore Pte Ltd. 2017. Pp. 29-60.

[21]. Johnstone, Leanne. Elinorsvärd-Sandin And Cecilia Lindh.(2017). The Scandinavian Cooperative Advantage?A Mixed Method Approach To Highlight The Influence Of Contextual Conditions For Environmental Csr Uptake. International Journal Of Environment And Sustainable Development.16(4). Pp. 336-358

[22]. Kristina, Anita. 2010. The Model Of Training Needs Analysis To Create Innovative Behavior Of Human Resources For Shoes Small Industry In East Java. Equity, 14 (No. 4 December 2010). Pp: $434-459$.

[23]. Leonard, Llewellyn. (2018). Coverging Political Ecology And Environmental Justice Discipline For More Effective Civil Society Actions Against Macro-Economic Risks: The Case Of South Africa. International Journal Of Environment Development.17 (1).Pp.1-18.

[24]. Lynch,Clifford. (2000) Authenticity And Integrity In The Digital Environment: An Exploratory Analysis Of The Central Role Of Trust. Council On Library And Information Resourcespublication.Wahington Dc.Pp.32-50.

[25]. Nelson, Katia. Jean-Sébastien Boudrias. Luc Brunet. Denis Morin. Mirella De Civita. André Savoie And Marie Alderson. 2014. Authentic Leadership And Psychological Well-Being At Work Of Nurses: The Mediating Role Of Work Climate At The Individual Level Of Analysis. Journal Homepage: Www.Elsevier.Com/Locate/Burn. Burnout Research 1 (2014) . Pp:90-101.

[26]. Policy Brief (Eager. 1999) Authentic And Sustained Civil Service Reform In Africa Is Possible, Given Domestic Political Consensus That Bureaucratic Incompetence And Corruption Are Serious Obstacles To Development.Eme And Emeh (2012.P.34) The Role Of Bureaucracy Is Critical To All Areas Of The Development Process In Nigeria.

[27]. Poor, Javadasad And David Thorpe.(2017). Pro-Environmrntalbehaviours In Improving Energy Performance Of The Australia Housing.International Journal Of Environment And Sustainable

[28]. Puspita, Astrini Ayu. 2014. The Study On The Performance Of Village Government In Creating Green Village Residence Program In Gayamsari Village, Semarang City, Journal Of Area And City Development, Volume 10 (3. September 2014): 355-368.

[29]. Schiller, Maria. (2017). “Authenticity Or Skill-Oriented Individualism, Neutrality Or Managerialism:

[30]. Smith (1991) The Bureaucracy Is Essential To Ensure Legitimacy Of Rule And To Promote The Concept Of The Public Administrator As The Servant Of The People.

[31]. Smith, Thomas B. (1991).“The Comparative Analysis Of Bureaucratic Accountability.”Asian Journal Of Public Administration.13 (.L .Juny 1991). Pp. 93-104. Studies.43(10).Pp.1662-1678.

[32]. Sutiyo And Ismail Nurdin. 225. Institutional Membership And Rural Development In Indonesia: Case Study Of Three Villages In Purbalingga. Community Journal, 7 (2) (2015): 224-135.

[33]. Van Auken, Howard. 2008. Innovation And Performance In Spanish Manufacturing Smes. Int. J. Entrepreneurship And Innovation Management. 8( 1). Pp:38-56.

[34]. Vanhoonacker, Sophie. Hylkedijkstra. Heidi Maurer. (2010). Understanding The Role Of Bureaucracy In The European Security And Defence Policy: The State Of The Art. European Integration Online Papers.14 (Art.4).Pp.1-33.

[35]. Yao, Xianbin. And Venkatchalamanbumozhi. (2015). "Low Carbon Green Growth As An Inclusive Development Model: Assessing Policy Changes And Initial Lessons From Developing Asia. The International Journal On Green Growth And Development.1(1). Pp. 15-38. 